\title{
A Cases Relationship Between Internal Locus Control and Vocational Maturity Among Students in Medan, Indonesia
}

\author{
Nafeesa \\ Faculty of Psychology, University Medan Area, Indonesia \\ Eryanti Novita \\ Faculty of Psychology, University Medan Area, Indonesia \\ Erlina Sari Siregar \\ Faculty of Psychology, University Medan Area, Indonesia
}

Received: December 20, 2018 Accepted: February 18, 2019 Published: February 25, 2019

doi: 10.5296/jsss.v6i2.14426 URL: https://doi.org/10.5296/jsss.v6i2.14426

\begin{abstract}
Nowadays, education is an unseperatble part of indivudials' career succesfull. Vocational schools play an important role to increasing the chance to individuals get a future bright of their career life. The paper shows an effort to explain the relationship between internal locus of control with vocational maturity among vocational students in Medan, Indonesia. A total of 115 respondents were selected from 460 of total population in a public vocational school. Data were collected through a survey among the participants manually and the research employs the Pearson Correlation to analyze the data and test the hypothesis. Result pointed out that correlation coefficient $r_{x y}=0,562$ with $p$ value $=0.000(p<0,050)$. In summary, the internal locus of control as the independent variable has a relationship with the vocational maturity.
\end{abstract}

Keywords: Internal locus of control, Vocational maturity, Students, Medan

\section{Introduction}

The introduction and understanding of careers prospect should be carried out as early as possible to avoid failures in vocational elections (Heusdens, Baartman, \& de Bruijn, 2018). 
Doubts in choosing a job or education that will be carried out lead to difficulties in determining the direction of job choice, and obtaining employment in the future (Holmegaard, Ulriksen, \& Madsen, 2014). In the term of schooling area, students' vocational knowledge is essential, because one of the problems faced by students after completing their studies is related to official and job selection (Ya-wen \& Yu, 2017). Vocational Maturity is the achievement of individuals who function as different vocationalities during vocational development, by showing the behavior needed to plan, find information, and provide information about what can be taken to make a career. Vocational knowledge is how success of individuals completing their task of typical vocational development at the stage of vocational development, by showing the behaviors needed to plan vocational, seek information, have insight into the world of work and have an awareness of what is needed in making career decisions (Erman, Sahan, \& Balci, 2015).

The quality of vocational selection by individuals is determined by their level of vocational maturity (Komandyahrini, 2008). Therefore vocational maturity is needed by students so that they can choose and prepare themselves to enter a career well (Yang, Liao, \& Chou, 2015). Although the Vocational Schools are expected to be able to produce graduates ready for work, in reality, open unemployment is mostly from Medan, Indonesia. According to Badan Pusat Statistik, which is the The Indonesian Government Institution which organizes statistical issue in Indonesia, stated that the unemployment rate in North Sumatra in February 2018 was 5.59 percent or as many as 403 thousand people are unemployed. The number is higher rather than another province such as Aceh, West Sumatra, and Jambi (http:/www.bps.go.id). So, it can be concluded that North Sumatra has the higher rate of unemployment in Sumatra island of Indonesia.

Based on the Super's theory of vocational, individuals' vocational maturity locus of control is one of the factor that influence it. Individiual with a good internal locus of control believe events in their life derive primarily from their own actions (Super, 1953). What happened to him was more caused by factors in him, he felt able to regulate all actions, actions, and environment. Individuals with an internal locus of control are more likely to be active, diligent, resilient, independent, more effective in completing tasks and more sensitive to information that is relevant to their situation. That is why they are more likely to be responsible for their mistakes and failures (Solomon \& Oberlander, 1974). Hence, students who have an internal locus of control, when faced with vocational elections, then they will make an effort to recognize themselves. This paper is aiming to identify the relationship between the internal locus of control and vocational maturity of vocational students in Medan, Indonesia. Theories, methodology, and the result of the study will be discussed further.

\section{Theory and Related Works}

Making the vocational choices for each individual can provide an understanding of oneself, self-concept as time passes. Career satisfaction can be sought with work roles, and moreover, individuals can also express and apply self-concept by working (Super, 1953). According to Super (1953), career development emphasizes the importance of developing a self-concept. Then, this self-concept can change according to new experiences in each period. So, Super states that career development is a struggle that every individuals should face in their lifetime. According to Rotter (1954), locus of control affecting the learning process of individuals, but 
in different situations, also it explains how the individual attach events to their behaviors in a given situation.

Locus of control can be illustrated as a characteristic of an individual who can regulate one's level of motivation. Locus of control can be divided into two parts, namely internal and external. Internal locus of control refers to the effort and ability of one person to do something. In contrary, the external locus of control is for an individual to see other people who are more powerful or strong and encourage him to be better. An individual who has a high internal locus of control, then he will be responsible for his future and overcome any problems faced. So they assume that all situations are under their control (Rotter, 1954).

The relationship between locus of control and vocational maturity has been studied recently by researchers. A study by Akpochafo (2017) reported that locus of control has a correlation towards career decision making among secondary school students in Delta State of Nigeria. The research is organized. Moreover, Bahtiar (2017) organized a research to sought the relationshop between of locus of control and the career maturity of twelfth grade students of the accounting program in private vocational high schools. Yet, the result pointed out a similar expression between the studies' purpose and the outcome.

Munawir et al. (2018) conducted a study that investigate the affect of internal locus of control towards the career maturity of high school students. The study proposed that internal locus of control has a perception that the measures themselves would produce a positive thing that makes their work more successful. Then, Zahra and Malik (2018) designed a research to explore the relationship between self-concept and career maturity in high school students. The result pointed out a significant strong positive correlation between self-concept and career maturity among high school students. Then, Ulas and Yildirim (2018) conducted a study to determine the relationship between locus of control and career decision-making self-efficacy among final-year Turkish undergraduate students across various departments. The result found that relationship between locus of control and career decision-making self-efficacy was significant. To conclude, locus of control is convinced to have a strong relationship towards vocational maturity. Table 1 shows the summary of several previous studies regarding this issues.

Table 1. Studies related to locus of control and vocational maturity

\begin{tabular}{llll}
\hline No. & Author (Year) & Objective & Findings \\
\hline 1. & Akpochafo (2017) & locus of control and career decision making & Positive \\
2. & Bahtiar (2017) & locus of control and the career maturity & Positive \\
3. & Munawir et al. (2018) & internal locus of control and the career maturity & Positive \\
4. & Ulas and Yildirim (2018) & locus of control and career decision-making & Positive \\
5. & Zahra and Malik (2018) & self-concept and career maturity & Positive \\
\hline
\end{tabular}

\section{Methodology}

The study conducted by using the quantitative approach to gather the data from the 
respondents. This study wanted to find out the relationship between the internal locus of control and vocational maturity in students in the city of Medan. As causal research, the dependent variable (Y) that will be used in this study is vocational maturity while the independent variable (X) is the internal locus of control. According to Figure 1, Hypothesis 1 (H1) is the hypothesis that indicates that internal locus of control has a positive relationship towards vocational maturity.

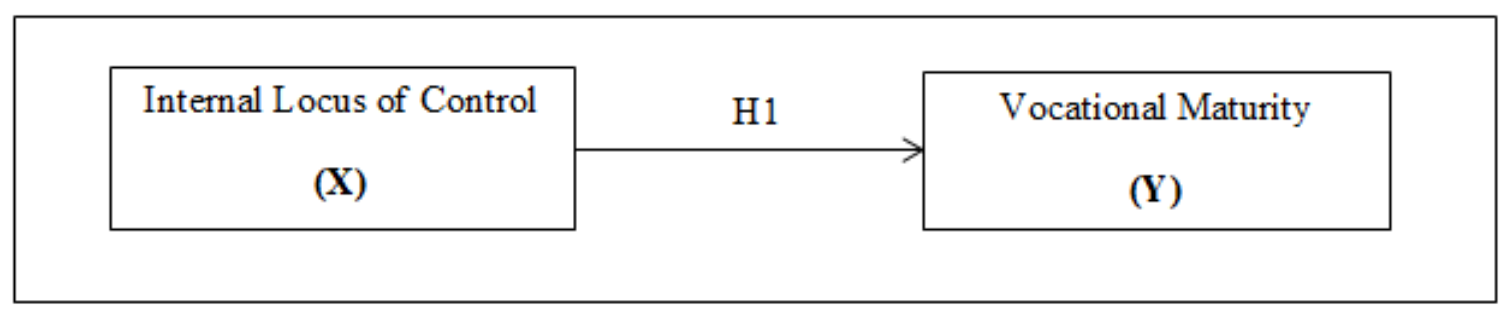

Figure 1. Conceptual framework of the study

Lau (1988) defined locus of control as self-control relating to matters relating to behavioral problems of the individual concerned. Individuals with high self-control will see that they can control their behavior. This opinion is supported by Sarafino and Smith (2014) which stated that individuals with internal locus of control believe that successes and failures that occur in life

depend on themselves. Thus, in this research, internal locus of control defined as the individual's beliefs about events that influence his life due to his behavior so that he can be controlled by himself. Vocational maturity is a series of roles or positions which include activities in work, leisure time, voluntary work and education (Seligman, 1994). Individuals should pass a stage of development that includes long periods of time to settle on a particular career (Winkel \& Hastuti, 2004). Hence, this study accounts vocational maturity as the crucial part that influences the career development of the individual.

Medan is the capital city of the North Sumatra and the fourth largest city in Indonesia behind Bandung, Surabaya, and Jakarta (A. H. Lubis, Idrus, \& Sarji, 2018). There are numbers of the vocational school in Medan, Indonesia. The research selected one of public vocational school in Medan with total population 460 of 12th grade students. Arikunto (2006) suggested that if the population is less than 100 people, thus the total sample would be total population of study, but if the number of subjects is large, it can take between $10-15 \%$ or $20-25 \%$ or more. Based on the population number of 460 people, the research took a sample of $25 \%$, then obtained a sample of 115 students by employing Simple Random Sampling method.

The study employs the Cronbach's alpha $(\alpha)$ to test the data reliability. Then, based on the reliability test, vocational maturity with total 37 items of instrument, has the $\alpha$ value $=0,888$. Then, Internal locus of control scale with total 37 items obtained a great Cronbach's alpha $(\alpha)$ score as much as $=0,845$. By the accordance with Hair et al. (2006), the instrument was classified in a good reliability. The process of collecting data only use the primary data that obtained initially from the respondents. Through the primary data collection method, the questionnaire was distrbuted to the students utilizing hard-copy paper. The technique of the 
analysis that will be used in this study is the Pearson Correlation. The method is a statistical analysis techniques to test correlative oriented hypotheses in order to see the relationship between one independent variable and non-independent variables (Lubis \& Osman, 2015).

\section{Results and Discussion}

The results of the analysis with the Product Moment correlation analysis method shows that there is a positive relationship between internal locus of control and vocational maturity, with the value of $r_{x y}$ coefficient $=0.562$ with a significant $p$ value $=0.000<0.050$. Thus, the Hypothesis 1 (H1) proposed that higher internal locus of control resulting the higher vocational maturity and it is fully accepted. The summary of the result is illustrated in Table 2 .

Table 2. Pearson correlation result

\begin{tabular}{llll}
\hline Statistic & Coefficient $\left(\boldsymbol{r}_{\boldsymbol{x} y}\right)$ & Coefficient Determination $\left(\boldsymbol{r}^{2}\right)$ & P value \\
\hline $\mathrm{X}-\mathrm{Y}$ & 0.562 & 0.316 & 0.000 \\
\hline
\end{tabular}

The determinant coefficient $\left(r^{2}\right)$ of the relationship between the independent variable $\mathrm{X}$ and the dependent variable $\mathrm{Y}$ is equal to $r^{2}=0.316$. This shows that internal locus of control contributes to vocational maturity of $31.6 \%$. Based on the results of this study, the proposed hypothesis was yet declared accepted. Based on data analysis, as seen from descriptive analysis, it is known that the empirical mean of the internal locus of control variable is 113.26, whereas for vocational maturity variables, the empirical mean is 116.83 .

The results of this study are in accordance with the results of previous studies (Akpochafo, 2017; Bahtiar, 2017; Munawir et al., 2018; Ulas \& Yildirim, 2018; Zahra \& Malik, 2018) that showed a positive and significant relationship between internal locus of control and vocational maturity. Based on the description, it was concluded that research and hypotheses were accepted.

\section{Conclusion}

Based on the results obtained in this study, it can be concluded as follows: There is a positive relationship between internal locus of control and vocational maturity ( $r_{x y}=0.562$ with $p$ value $=0.000<0.050$ ). Thus, it is a positive relationship between internal locus of control and vocational maturity of students, where the higher the internal locus of control, the vocational maturity of students is also higher, and vice versa if the student's internal locus of control is low then vocational maturity of students is too low.

A contribution given by internal variable locus of control with vocational maturity is $31.6 \%$ of the percentage of this contribution, so there is still $68.4 \%$ influence from other factors besides the vocational maturity.

\section{References}

Akpochafo, G. O. (2017). Locus of Control as Correlate of Career Decision Making among Secondary School Students in Delta State of Nigeria. Journal of Educational and Social Research, 7(2), 25-30. https://doi.org/10.5901/jesr.2017.v7n2p25 
Arikunto, S. (2006). Prosedur penelitian suatu pendekatan praktik. Jakarta: Rineka Cipta.

Bahtiar, M. D. (2017). The Influence Of Locus Of Control, Self-Efficacy, And Accounting Achievement Learning On Accounting Career Maturity Of The Twelfth Grade Students Of The Accounting Program In Private Vocational High Schools. International Journal of Education, 10(1), 53-59. https://doi.org/10.17509/ije.v10i1.4679

Erman, K. A., Sahan, A., \& Balci, Y. K. (2015). The Vocational Maturity of School of Physical Education and Sports Students. Procedia-Social and Behavioral Sciences, 174, 2380-2383. https://doi.org/10.1016/j.sbspro.2015.01.904

Hair, J. F., Black, W. C., Babin, B. J., Anderson, R. E., Tatham, R. L., \& others. (2006). Multivariate data analysis (Vol. 6). Upper Saddle River, NJ: Pearson Prentice Hall.

Heusdens, W. T., Baartman, L. K. J., \& de Bruijn, E. (2018). Knowing everything from soup to dessert: an exploratory study to describe what characterises students' vocational knowledge. Journal of Vocational Education \& Training, 1-20. https://doi.org/10.1080/13636820.2018.1437065

Holmegaard, H. T., Ulriksen, L. M., \& Madsen, L. M. (2014). The process of choosing what to study: A longitudinal study of upper secondary students' identity work when choosing higher education. Scandinavian Journal of Educational Research, 58(1), 21-40. https://doi.org/10.1080/00313831.2012.696212

Komandyahrini, E. (2008). Hubungan Self Efficacy dengan Kematangan dalam Memilih Karir Siswa Program Percepatan Belajar. Jurnal Keberbakatan Dan Kreativitas, 2(1), 1-12.

Lau, R. R. (1988). Beliefs about control and health behavior. In Health Behavior (pp. 43-63). Springer. https://doi.org/10.1007/978-1-4899-0833-9_3

Lubis, A. H., Idrus, S. Z. S., \& Sarji, A. (2018). ICT Usage Amongst Lecturers and Its Impact Towards Learning Process Quality, 34(1), 284-299.

Lubis, Z., \& Osman, A. (2015). Statistik dalam Penyelidikan Sains Sosial: Aplikasi dan Falsafah. Penerbit Universiti Malaysia Perlis.

Munawir, M., Yusuf, A. M., Effendi, Z. M., \& Afdal, A. (2018). Internal Locus of Control and Self-Concept as Factors Affecting the Career Maturity of High School Students. International Journal of Research in Counseling and Education, 1(2), 24-31. https://doi.org/10.24036/0018za0002

Rotter, J. B. (1954). Social learning and clinical psychology.

Sarafino, E. P., \& Smith, T. W. (2014). Health psychology: Biopsychosocial interactions. John Wiley \& Sons.

Seligman, L. (1994). Developmental career counseling and assessment. Sage Publications, Inc.

Solomon, D., \& Oberlander, M. I. (1974). Locus of control in the classroom. Psychological Concepts in the Classroom. New York: Harper \& Row, 119-150.

Super, D. E. (1953). A theory of vocational development. American Psychologist, 8(5), 185. https://doi.org/10.1037/h0056046

Ulas, O., \& Yildirim, \.Ibrahim. (2018). Influence of locus of control, perceived career barriers, negative affect, and hopelessness on career decision-making self-efficacy among 


\section{IIMacrothink}

Journal of Social Science Studies

ISSN 2329-9150 2019, Vol. 6, No. 2

Turkish university students. International Journal for Educational and Vocational Guidance, 1-25. https://doi.org/10.1007/s10775-018-9370-9

Winkel, W. S., \& Hastuti, S. (2004). Bimbingan karir di institusi pendidikan. Jakarta: Media Abadi.

Ya-wen, W., \& Yu, H. (2017). On the Essential Attributes of Vocational Education Knowledge. Vocational Education Research, 8, 4.

Yang, M.-Y., Liao, Y.-Y., \& Chou, Y.-P. (2015). The vocational maturity and career choices of female industrial design students in Taiwanese universities. Art, Design \& Communication in Higher Education, 14(1), 23-37. https://doi.org/10.1386/adch.14.1.23_1

Zahra, S. T., \& Malik, A. A. (2018). Relationship between Self-concept and Career Maturity in Pakistani High School Students. Bahria Journal of Professional Psychology, 17(1).

\section{Copyright Disclaimer}

Copyright for this article is retained by the author(s), with first publication rights granted to the journal.

This is an open-access article distributed under the terms and conditions of the Creative Commons Attribution license (http://creativecommons.org/licenses/by/3.0/). 